\title{
Scientific Computers at the Helsinki University of Technology during the Post Pioneering Stage
}

\author{
Panu Nykänen and Hans Andersin \\ Helsinki University of Technology \\ panu.nykänen@tkk.fi, hans.andersin@tkk.fi
}

\begin{abstract}
The paper describes the process leading from the pioneering phase when the university was free to develop and build its own computers through the period when the university was dependent on cooperation with the local computer companies to the stage when a bureaucratic state organization took over the power to decide on acquiring computing equipment to the universities. This stage ended in the late 1970s when computing power gradually became a commodity that the individual laboratories and research projects could acquire just like any resource. This development paralleled the situation in many other countries and universities as well. We have chosen the Helsinki University of Technology (TKK) as a case to illustrate this development process, which for the researchers was very annoying and frustrating when it happened.
\end{abstract}

Keywords: Computing science, education, computing centre.

\section{The Finnish State Computing Centre}

The happy pioneering phase [3, 6] in the 1940s and 1950s when scientific university institutions used to design and build their scientific computers preceded the era of commercially produced scientific computers. The Committee for Mathematical Machines (Matermatiikkakonekomitea-Matematikmaskinkommit-tén) finished their task in the beginning of the 1960s. After a period of interregnum, the state responsibility for data processing matters transferred to the Finnish State Computing Centre (FSCC) that was founded in 1964. Actually, it had already started to operate earlier [4]. Before FSCC came into existence, an unsuccessful attempt was made in 1963 by the Academy of Engineering Sciences to form a national center for scientific and engineering computing [2].

Due to scarce financial resources available for acquiring computers, the university scientific staff lost their decision-making rights as to computer acquisition and resource allocation. The bureaucrats took over both within and outside the universities. In Finland, the Ministry of Finance on a yearly basis allocated funds for computer acquisition. When a university wanted to use the allocated funds for buying a new computer, it had to get the approval for its plans by the FSCC. In many cases, the situation deteriorated into open and bitter conflicts of interest. FSCC wanted to sell their services and computing capacity to the universities instead of letting them buy their own computers. FSCC also wanted to push certain computer brands instead of giving the universities free hands. One of the reasons was their belief in the blessings 
of standardization. Another reason was that the bureaucrats generally mistrusted the competence of university professors to make rational decisions in selecting the best computer.

FSCC acquired its first large-scale scientific computer, an Elliott 503, in the mid1960s. Interestingly enough, they physically placed it in the Helsinki University of Technology (HUT, in Finnish TKK) main building and TKK students and research workers heavily used it.

\section{The Finnish Cable Works Becomes a Major Player}

In December of 1958, Björn Westerlund was chair and CEO of the Finnish Cable Works (later Nokia). He suggested to the board of directors that one could add computers to the product program of the company. This resulted in giving the mathematician Olli Lehto (today a member of the Academy of Finland) the task of founding an electronic division within the Cable Works. In addition to Lehto the Cable Works' Electronic Division hired Tage Carlsson who then worked with the Committee for Mathematical Machines. They also added Lauri Saari from VTT (State Institute of Technical Research and Development) to the staff of the Electronic Division. When IBM - that already had Hans Andersin from the Committee of Mathematical Machines on board - hired Olli Varho (who later became the president of IBM Finland) from the Committee, this meant that all the key resources of the Committee were divided between the two major players in the computer market in Finland [3].

In the beginning, the Finnish markets alone were not big enough to attract other large international computer companies except IBM. During the cold war period, however, the Finnish foreign trade was heavily directed towards the Soviet Union and the big international computer companies apparently wanted to take advantage of this situation. In 1961, this led to agent agreements between the Cable Works and the French Compagnie des Machines Bull (CMB) with punched card machines and the computers Gamma 10 and Gamma 30 on one hand and the Swedish Facit with peripheral equipment on the other. Earlier the Cable Works already had agreements with the German Siemens and the British Elliott Brothers The agreements included sale to the Soviet Union [1].

The Finnish computer market was from now on for some time divided between IBM and the Cable Works (representing CMB, General Electric, Siemens, Facit, and Elliott). The Helsinki University of Technology (TKK) had to balance between these two major players. Cable Works was more technically and less commercially oriented than IBM and it attracted the engineers both at TKK and at VTT Technical Research Centre of Finland.

\section{The First Scientific Computers at HUT/TKK}

For users of scientific computers there were several possibilities to use computers outside TKK. Many scientists used the Postal Savings Bank IBM 650, the first operational computer in Finland, for their scientific and engineering computing needs already at the end of the 1950s. In 1960 TKK started to use the newly acquired Elliott computers (803 and later 503) of the Finnish Cable Works. When the Northern 
Europe University Computing Centre (NEUCC) opened in Copenhagen in the mid1960s, equipped with a world class scientific IBM 7090, many TKK users were among its clients. In addition, many of the companies having acquired computers suitable for scientific applications made their equipment available for TKK users.

Despite the abundance of computing power available outside TKK, the university appointed in September of 1960 a committee to investigate the need for computers inside TKK. The committee was chaired by Professor Erkki Laurila (Prof. of Technical Physics, later member of the Academy of Finland) with Professor Pentti Laasonen (Prof. of Strength of Materials) and assistant professor Olli Lokki (Prof. of Applied Mathematics) as members. The committee recommended that a scientific computer be acquired by TKK to avoid being too dependent on outside computers. Additionally, the computer education would require, according to the committee, that the students experience a possibility for "hands on" use of computers. The committee did not believe that the idea of the Finnish State providing a centralized computing resource would materialize for a long time to come. On the contrary, TKK could sell computer excess time to the State [7].

Because the computer would require local maintenance service and cooperation with the computer manufacturer, the feasible alternatives were only the IBM 1620 and the Elliott 803. The final decision was in favor of the Elliott computer due to the higher maintenance cost of the IBM machine and because the Computer Center of the Helsinki University had just decided in favor of the IBM 1620. IBM submitted a new proposal to TKK in March that in economic terms was almost identical to the Cable Work's proposal. This proposal was turned down but the IBM offer to give free computer time to TKK was gratefully accepted [8]. Consequently, the decision occurred by a wish to strike a balance between the two main players in the Finnish market. It was clearly also a gesture of friendship towards the Finnish Cable Works that had just begun its struggle for market shares in the Finnish Market.

The funds needed for the purchase were allocated in the State budget in January 1961 and in March, they made the decision to fund a computing Center at TKK. Rector Jaakko Rahola was to sign the agreement with the Cable Works. One of the motives for acting swiftly was the fact that computers got obsolete in no time at all. If TKK had not approved the delivery of the one-year-old Elliott 803, the delivery time of an updated version would have stretched out to be at least nine months. The Cable Work's Elliott 803 was free for delivery in April of 1961, which implied that the computer education would begin the same year. The university placed the TKK Computing Centre as a part of the Institution for Applied Mathematics. Later, they replaced the 803A with an 803B and simultaneously they added an IBM 1620 to the equipment of the TKK Computer Centre, probably in order to create a balance between the two main competitors IBM and the Cable Works.

When TKK Computer Centre moved 1968 from the old facilities of TKK in Helsinki City Centre to the Otaniemi Campus area, the laboratory got better possibilities for independent work.

\section{The Bank of Finland Enters the University Computer Scene}

A large step towards centralized university computing in Finland occurred during the end of the 1960s when the Bank of Finland allocated funds for acquiring large-scale 
scientific computing capacity to the universities in Finland. They purchased a Sperry Rand Univac 1108 and gave it to the FSCC to run. This caused a massive protest action among the universities that feared that the dictatorial FSCC would now put an end to all independent purchase of computers by the universities. As a compromise, they allowed the universities to buy terminal computers and equipment; they purchased 150 terminals and placed them at the universities all around the country.

TKK was very discontent with the situation but was finally able in 1970 to purchase a modern time sharing system, Hewlett Packard 2000, which served the basic courses of computer programming during some years to come [5]. The situation with regard to increasing the capacity of the TKK computing centre did not improve, however. The strategy of the bureaucrats was still to maximize the use of the centralized scientific computer capacity at the FSCC by allocating new computer money only to the peripheral universities. TKK was of the opinion that this strategy had stalled its development for nearly a decade. An interesting part of the history of computing at TKK, was the 1974 purchased MIR-2 computer that was manufactured by Kievskij Zavod elektronnyh vytsislitelnyh $i$ upravljajuštšihmašin in USSR. They acquired the computer as a part of the bilateral export - import agreement between Finland and USSR, and as the payment for it was a huge amount of surplus eggs. Some of the bureaucrats could see MIR-2 as an addition to the computing capacity of TKK, but the director of the TKK computing center, Olli Lokki, warned of this point of view in his inauguration speech. Instead, TKK's own and several western researchers keenly familiarized themselves with MIR-2 as a rare example of a Soviet way to design computer architecture $[9,5]$.

A rebellious act by TKK was to save the money that had been allocated for other investments and expenses and use the resulting funds to buy a new computing system without asking anyone's permission. They installed a Digital Equipment Corporation's DEC System 20 during the first half of 1978 at the TKK Computer Centre and it served well for almost ten years.

Some of the research groups at TKK were able to obtain permission to buy their own computers. Most of these were minicomputers such as the PDP-8, PDP-11, and PDP-15 that started to appear in various laboratories in the beginning of the 1970s, mostly in dedicated applications such as process control tasks. The purchases of such small computers became deregulated and the discontent with FSCC among the university research staff diminished.

\section{Concluding Remarks}

The commercialization of computer and software design and manufacturing affected the universities in several ways. A positive result was the fact that most of the new commercial computers were more reliable and had more software capabilities than the ones built in the universities. At the same time, the need for scientific computing capacity grew beyond all limits at the universities and the government took the power to control the use and purchasing of the machinery. A negative result of the commercialization was that the innovative power and specialized know-how of university research workers was left untapped. This development was typical for most small countries. 
One of the reasons for the State centralized computer policy was the wide spread belief in the blessings of standardization. It looked like that the bureaucrats generally mistrusted the competence of university professors to make rational decisions in selecting the best computer.

Despite of the limiting and often frustrating restrictions put on the universities, TKK was able to find the right shortcuts and ways to stay in the main stream of the development during the period of two decades covered by this report. We could observe five different strategic directions. These include: (a) Some TKK institutions continued to build special purpose computers for their own use, (b) some TKK institutions used outside computer resources for fulfilling their needs for computing power, (c) the establishment of a TKK computing center, (d) TKK took part in using FSCC computer resources, and (e) some TKK institutions bought computers for their own use.

\section{References}

[1] Aaltonen, A.: Nokian elektroniikkateollisuuden synty: nuorten kokeilijoiden ja keksijöiden pajasta huipputeollisuudeksi. In: Tienari, M. (ed.) [The birth of the electronics industry at the Nokia Corporation], pp. 118-119. Tietotekniikan alkuvuodet Suomessa. Gummerus Kirjapaino Oy, Jyväskylä (1993)

[2] Nykänen, P.: Tekniikan tiennäyttäjät. Teknillisten tieteiden akatemia 1957-2007. In: [The history of the Finnish Academy of Technology] Gummerus Kirjapaino Oy, Jyväskylä, pp. 47-48 (2007)

[3] Paju, P.: "Ilmarisen Suomi" ja sen tekijät. Matematiikkakonekomitea ja tietokoneen rakentaminen kansallisena kysymyksenä 1950-luvulla. English Summary [Building "Ilmarinen's Finland". The Committee for Mathematical Machines and computer contruction as a national project in the 1950s]. Turun yliopiston julkaisuja C 269, 440-457 (1950)

[4] Pietarinen, I.: Kun Suomen tietotekniikkaa ohjailtiin neuvottelemalla - Tietotekniikan neuvottelukunta 6.11.1975 - 31.12.1991. In: Tienari, M. (ed.) [The history of the committee of the information technology], pp. 273-274. Tietotekniikan alkuvuodet Suomessa, Gummerus Kirjapaino Oy, Jyväskylä (1993)

[5] Sarlin, K.: TeKoLan 30-vuotinen taival. In: [The history of the Helsinki University of technology Computer Centre]. Teknillinen korkeakoulu, Laskentakeskus, TKK OFFSET, pp. 4, 8, 9-12 (1991)

[6] Seppänen, J.: 30 vuotta tietokoneaikaa Teknillisessä korkeakoulussa. Historiaa ja muistikuvia Eskon ja Elliottin ajoilta. [30 years of computers at Helsinki University of Technology TKK] Teknillinen korkeakoulu, Laskentakeskus. Otaniemi (1991)

[7] TKKA The archives of Helsinki University of Technology TKK, Espoo that include the archives of the Executive Committee (Hallintokollegi, HK) and the archives of the Administrative Council (Opettajaneuvosto, ON). TKKA ON 15.12.1960, § $4+$ liite muistio Erkki Laurila \& Pentti Laasonen \& Olli Lokki Osamietintö Teknillisen Korkeakoulun elektronikonetarpeesta 3.12.1960. TKKA HK 30.1.1961, § 10 + liite Erkki Laurila \& Pentti Laasonen \& Olli Lokki 20.1.1961 Teknillisen korkeakoulun elektronikonetarvetta käsittelemään asetetun komitean mietintö

[8] TKKA HK 20.3.1961, § 7 and $\S 8$.

[9] Unpublished report Katsaus laskentakeskuksen toimintaan vuosina 1961-72 ja toiminnan kehittämisen lähitavoitteet. 9.4.1973. pp. 18-19. [A short history of TKK Computer Centre 1961 - 72] 